\title{
Mycoplasma collis, a New Species Isolated from Rats and Mice
}

\author{
AURIOL C. HILL \\ Medical Research Council Experimental Embryology and Teratology Unit, Carshalton, Surrey SM5 4EF, \\ England
}

Mycoplasmas isolated from the conjunctivas and nasopharynges of rats and mice were shown to be serologically distinct from 78 previously recognized Mycoplasma and Acholeplasma species. Three cloned strains obtained from separate animal colonies were examined in detail. These strains were indistinguishable from each other. Strain 58B $(=$ NCTC 10197) is designated the type strain of a new species, Mycoplasma collis.

Four Mycoplasma species are known to infect rats and mice; these species are Mycoplasma arthritidis, Mycoplasma muris (18), Mycoplasma neurolyticum, and Mycoplasma pulmonis. The isolation of an additional species from one mouse colony and three rat colonies has been reported previously (11). In one colony this species was associated with conjunctivitis, although other potential pathogens were also present on the conjunctivas $(10,11,32)$. In this paper I characterize this organism and propose that it should be classified as a new Mycoplasma species.

\section{MATERIALS AND METHODS}

Mycoplasma strains. Mycoplasmas were isolated from the conjunctivas of all rats in two colonies and from the nasopharynges of a few of these animals. In the first colony, the organisms, which were associated with conjunctivitis, were also recovered from brains. One cloned isolate from this colony was designated strain $58 \mathrm{~B}^{\mathrm{T}}$ ( $\mathrm{T}=$ type strain). Strain LIL was a cloned conjunctival isolate from the second colony. This organism was also isolated from swabs taken from the nasopharynges of the eight (strain $\mathrm{C}_{3} \mathrm{H}$ ) mice examined in a third colony (conjunctival swabs were not taken). One isolate was cloned and designated strain Gough. The unidentified isolates were cloned five times by filtration through 220 -nm filters to produce pure cultures.

Mycoplasma species. Mycoplasma type cultures were obtained from the National Collection of Type Cultures, Colindale, England, and from M. F. Barile, J. M. Bradbury, R. J. Fallon, E. A. Freundt, J. T. Heywood, F. T. W. Jordan, D. E. Jasper, H. Kirchhoff, R. H. Leach, G. Smith, D. Taylor-Robinson, and J. G. Tully.

Medium and growth conditions. The culture medium used has been described previously by Taylor-Robinson et al. (27) and Hill (9). The purified agar used in the growth medium was either lonagar no. 2 (Oxoid Ltd., Basingstoke, England) or Lab M agar (Lab M, Lon- don, England). Depending upon their biochemical activities, the mycoplasmas were grown in liquid medium containing $1 \%$ glucose $(\mathrm{pH} 7.8)$ or $1 \%$ arginine (pH 7.3). Agar cultures were incubated at $35^{\circ} \mathrm{C}$ either in a humid chamber or under anaerobic conditions in a GasPak system. Liquid cultures were stored at $-70^{\circ} \mathrm{C}$ in ampoules.

Growth requirements and characteristics. The strains were subcultured onto solid medium and grown for 1 week under both aerobic and GasPak anaerobic conditions at $35^{\circ} \mathrm{C}$. Inhibition of growth by methylene blue was investigated by adding $0.002 \%$ methylene blue to the basal solid medium. The production of a film was tested by inoculating mycoplasmas onto basal medium enriched with $10 \%$ egg yolk emulsion (6). The plates were examined at 3,7 , and 14 days.

Absence of reversion. The isolates were subcultured by five passages onto both solid and liquid media that contained no microbial inhibitors and were incubated aerobically to determine whether the organism reverted to a bacterial form. The isolates were also treated with Dienes stain (28).

Morphological studies. Mycoplasma colonies grown on agar were examined after 2, 7, and 14 days of incubation. The colonies were transferred to slides and stained with Giemsa stain $(7,14)$. Liquid cultures were observed under dark-field microscopy, and the organisms were stained with Giemsa stain (14). Organisms grown in broth were harvested by centrifugation, and the resulting pellet was fixed in $2 \%$ glutaraldehyde and postfixed in $1 \%$ osmium tetroxide. Thin sections were stained with uranyl acetate and lead citrate and examined by electron microscopy.

Filtration studies. Cultures (after $24 \mathrm{~h}$ of incubation) were diluted $1: 10$ in liquid medium and then filtered through a series of membrane filters (Millipore Corp.. Bedford, Mass.) with pore diameters of $100,220,300$, 450,650 , and $800 \mathrm{~nm}$. The titer (in colony-forming units) of each filtrate was compared with the titer of the original $1: 10$ culture dilution.

Sterol dependence. The mycoplasmas were seeded onto a serum-free solid medium supplemented with bovine serum albumin, glucose, and palmitic acid. Cholesterol dissolved in Tween 80 was added to give 
TABLE 1. Mycoplasma and Acholeplasma type strains used in serological comparisons

\begin{tabular}{|c|c|}
\hline Taxon & Taxon \\
\hline M. agalactiae. & $\ldots \ldots \ldots \ldots \mathrm{PG}_{21}{ }^{\mathrm{T}}$ \\
\hline M. alkalescens. & $M$. hyopneumoniae $\ldots \ldots \ldots \ldots \ldots \mathrm{J}^{\mathrm{T}}$ \\
\hline$\ldots \ldots \ldots \ldots \ldots$ & $M$. hyorhinis ........... BTS $7^{\mathrm{T}}$ \\
\hline$\ldots \ldots \ldots \ldots$ & M. hyosynoviae ........ \\
\hline M. arginini & $M$. iners . . . . . . . . . \\
\hline$M$. arthritidis & M. iowae .............. $695^{\mathrm{T}}$ \\
\hline$M$. bovigenitalium ..... & $M$. lipofaciens $\ldots \ldots \ldots \ldots \ldots \ldots$ R171 ${ }^{\mathrm{T}}$ \\
\hline 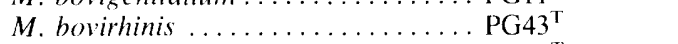 & 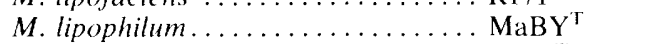 \\
\hline M. bovis ................ $4{ }^{4} 45^{\mathrm{T}}$ & M. maculosum ................ \\
\hline M. bovoculi............... $165 / 69^{\mathrm{T}}$ & $M$. meleagridis . . . . . . . . $\ldots \ldots \ldots 29^{\mathrm{T}}$ \\
\hline$M$. buccale $\ldots \ldots \ldots \ldots \ldots \ldots \ldots$ CH-20247 ${ }^{\mathrm{T}}$ & M. moatsii.................. \\
\hline M. californicum ............ ST $-6^{\mathrm{T}}$ & M. molare .................... \\
\hline M. canadense........... $275 \mathrm{C}^{\mathrm{T}}$ & M. muris .......... \\
\hline$\ldots \ldots \ldots \ldots$ & M. mustelae .......... \\
\hline M. capricolum .............. California $\mathrm{kid}^{\mathrm{T}}$ & M. mycoides subsp. capri \\
\hline M. caviae $\ldots \ldots \ldots \ldots \ldots \ldots \ldots{ }^{2} 122^{\mathrm{T}}$ & M. mycoides subsp. mycoides . \\
\hline$M$. citelli $\ldots \ldots \ldots \ldots \ldots \ldots \ldots \mathrm{RG}^{2} \mathrm{C}^{\mathrm{l}}$ & M. neurolyticum $\ldots \ldots \ldots \ldots \ldots$ Tyре $\mathrm{A}^{\mathrm{T}}$ \\
\hline M. columbinosale ......... . $694^{\mathrm{T}}$ & M. opalescens ............ MH5408 \\
\hline$M$. columbinam $\ldots \ldots \ldots \ldots \ldots \mathrm{MMP1}^{\mathrm{T}}$ & M. orale . . . . . . . . . . . . . . CH-19299 \\
\hline M. columborale . . . . . . . . . MMP4 & M. ovipneumoniae ............ Y9 $98^{\mathrm{T}}$ \\
\hline M. conjunctivae .............. HRC $581^{\mathrm{T}}$ & M. pneumoniae $\ldots \ldots \ldots \ldots \ldots \mathrm{FH}^{\mathrm{T}}$ \\
\hline M. cricetuli ............. $\mathrm{CH}^{\mathrm{T}}$ & M. primatum $\ldots \ldots \ldots \ldots \ldots \mathrm{HRC}_{292}{ }^{\mathrm{T}}$ \\
\hline$M . \operatorname{cynos} \ldots \ldots \ldots \ldots \ldots \ldots \ldots \mathrm{H} 831^{\mathrm{T}}$ & M. pullorum .... \\
\hline M. dispar.............. $462 / 2^{\mathrm{T}}$ & M. pulmonis ........ \\
\hline M. edwardii $\ldots \ldots \ldots \ldots \ldots \ldots \mathrm{PG}_{24}{ }^{\mathrm{T}}$ & M. putrefaciens.... \\
\hline M. equigenitalium ............ & $M$. salivarium ............ PG20 ${ }^{\mathrm{T}}$ \\
\hline M. equirhinis ............. $4432 / 72^{\mathrm{T}}$ & M. spumans .............. \\
\hline$M$ fastidiosum $\ldots \ldots \ldots \ldots \ldots \ldots 4822^{\mathrm{T}}$ & M. suahi................. Mayfield $\mathrm{B}^{\mathrm{T}}$ \\
\hline M. faucium .............. DC $333^{\mathrm{T}}$ & M. subdolum $\ldots \ldots \ldots \ldots \ldots \ldots \mathrm{TB}^{\mathrm{T}}$ \\
\hline M. feliminutum ............ Ben ${ }^{T}$ & M. synoviae .... \\
\hline$M$ felis $\ldots \ldots \ldots \ldots \ldots \ldots \mathrm{CO}^{\mathrm{T}}$ & $M$. verecundum \\
\hline M. fermentans ........... & A. axanthum.... \\
\hline M. flocculare ............. & A. equifetale.... \\
\hline M. gallinaceum ............ & A. granularum .. \\
\hline M. gallinarum ..... & A. hippikon .... \\
\hline M. gallisepticam $\ldots \ldots \ldots \ldots$ & A. laidlawii.... \\
\hline 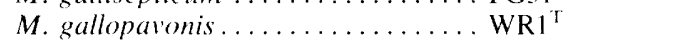 & A. modicum ... \\
\hline M. gateae ................ & A. morum ... \\
\hline$M$. genitalium $\ldots \ldots \ldots \ldots \ldots \ldots G \mathrm{G}-37^{\mathrm{T}}$ & A. oculi ............ \\
\hline
\end{tabular}

concentrations of $20,10,5$, and $1 \mu \mathrm{g} / \mathrm{ml}$. Plates containing no cholesterol were included (4. 5, 24, 30). The mycoplasmas were also subcultured onto medium without serum.

The isolates were tested for susceptibility by using disks containing $0.02 \mathrm{ml}$ of either a $1.5 \%$ ethanolic solution of digitonin (Sigma Chemical Co., St. Louis. Mo.) or a $20 \%$ aqueous solution of sodium polyanethol sulfonate (Koch-Light Laboratories Ltd., Colnbrook. England). The width of the zone of growth inhibition was measured in millimeters (8).

Biochemical activity. The isolates were examined for carbohydrate metabolism: for hydrolysis of esculin. arginine, and urea; for reduction of methylene blue. resazurin, tetrazolium, and tellurite; and for phosphatase activity $1,2,15,25,29,31)$.

Erythrocyte techniques. Hemolytic activity, adsorption, and agglutination of erythrocytes were tested with fowl, guinea pig, human, and sheep cells $(1,16)$.

Polyacrylamide gel electrophoresis. Electrophoresis was carried out as described by Razin and Rottem
(23). Centrifuged cell suspensions were dried, and 6 $\mathrm{mg}$ of each suspension was dissolved in $0.6 \mathrm{ml}$ of phenol-acetic acid-water $(2: 1: 0.5, \mathrm{vol} / \mathrm{vol} / \mathrm{vol})$. To the gels were added 0.025 - and $0.05-\mathrm{ml}$ portions of the cell sample. Electrophoresis was carried out at room temperature for $3.5 \mathrm{~h}$ at a constant current of $5 \mathrm{~mA} /$ tube, and the gels were then stained with $1 \%$ naphthol blue black.

DNA base composition. Deoxyribonucleic acids (DNAs) were extracted by the method of Kirby (13), and their guanine-plus-cytosine contents were determined from their thermal denaturation temperatures (17). DNAs extracted from Clostridium perfringens and Mycoplasma gallisepticum with known guanineplus-cytosine contents were included as controls.

Serological studies. Antisera were prepared as described previously by Morton and Roberts (19) and Hill (9). The following three tests were used: growth inhibition (3), metabolism inhibition $(12,21,22,26)$, and immunoperoxidase on colonies grown on agar (20). All tests were carried out in duplicate. Strains 
$58 \mathrm{~B}^{\mathrm{T}}$ and Gough were reacted with antisera prepared against the species listed in Table 1 . Antisera to strains $58 \mathrm{~B}^{\mathrm{T}}$ and Gough were tested with the named Mycoplasma and Acholeplasma species. Antisera to strains $58 \mathrm{~B}^{\mathrm{T}}$, Gough, and LIL were reacted with each other to demonstrate their relationships.

\section{RESULTS AND DISCUSSION}

Colonies of strains $58 \mathrm{~B}^{\mathrm{T}}$, Gough, and LIL were visible after 2 to 3 days of incubation under both aerobic and anaerobic conditions. The colonies (Fig. 1) had a typical fried-egg appearance. The growth characteristics are shown in Table 2.

No motility was observed under dark-field microscopy, and helical forms were not seen. Liquid cultures stained by Giemsa stain showed pleomorphic forms. The organisms were similar in ultrastructure to other mycoplasmas when they were viewed by electron microscopy. The cells were bounded by a single unit membrane and lacked any evidence of cell wall material (Fig. 2).

Filtration of the mycoplasmas showed that of $6 \times 10^{7}$ organisms per $\mathrm{ml}$ in the original dilution. reduced numbers passed through the 300-nm $(6$ $\times 10^{5}$ cells per $\left.\mathrm{ml}\right)$ and 220 -nm $\left(8 \times 10^{4}\right.$ cells per $\mathrm{ml}$ ) membranes and that no organisms passed through the 100-nm membrane.

These organisms required cholesterol (1 $\mu \mathrm{g} / \mathrm{ml}$ ) for growth. They were susceptible to digitonin and sodium polyanethol sulfonate, with zones of growth inhibition of 9 and 7 to 8 $\mathrm{mm}$, respectively.

The strains related to strain $58 \mathrm{~B}^{\mathrm{T}}$ belong to the genus Mycoplasma, because they are nonhelical, depend upon sterol for growth, and are susceptible to digitonin and sodium polyanethol

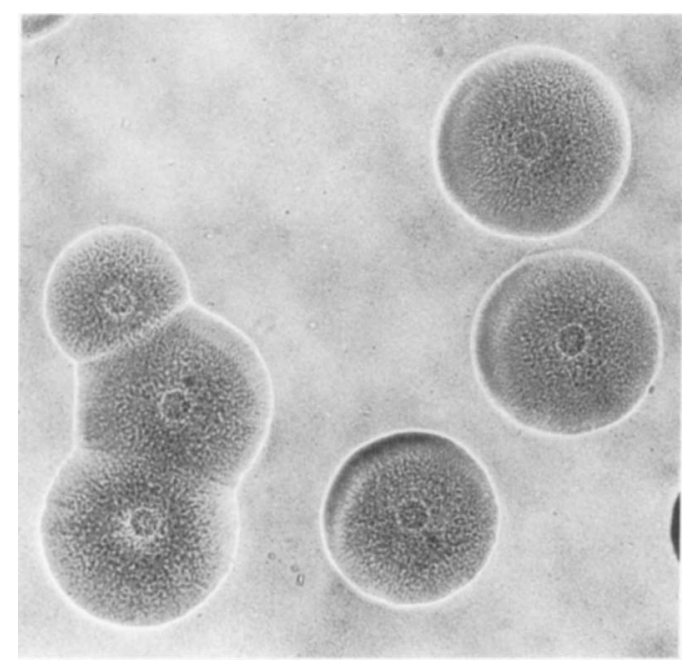

FIG. 1. Colonies of strain $58 \mathrm{~B}^{\mathrm{T}}$ grown aerobically for 4 days on an agar medium. $\times 45$. sulfonate and because urease could not be demonstrated.

Biochemical activities are shown in Table 2. The strains metabolized some carbohydrates (glucose, maltose, mannose, and sucrose) but did not hydrolyze arginine or ferment arabinose, arbutin, cellobiose, dulcitol, fructose, galactose, glycerol, inositol, lactose, mannitol, raffinose, rhamnose, salicin, sorbitol, trehalose, or xylose. They lysed but did not adsorb or agglutinate erythrocytes.

The three strains gave similar electrophoretic protein patterns, and these patterns were distinct from those of the previously decribed rodent mycoplasmas. The pattern of strains $58 \mathrm{~B}^{\mathrm{t}}$ is compared with the pattern of $M$. pulmonis in Fig. 3.

The DNA was denatured at midpoint temperatures of 80.75 to $81.0^{\circ} \mathrm{C}$ (corrected for thermal expansion) in several tests. The guanine-pluscytosine content of $28 \mathrm{~mol} \%$ was determined by the following equation: $T_{m}=69.3+0.41$ (guanine-plus-cytosine content), where $T_{m}$ is the thermal denaturation temperature (17). This value is similar to the values obtained for other Mycoplasma species. This result agreed with that obtained by A. Liss, New York, N.Y., who examined DNA extracted from strain 58B (personal communication).

Serological techniques showed high levels of cross-reactions among the three isolates (Table 3). No cross-reactions were detected with any of the species listed in Table 1.

TABLE 2. Colonial and biochemical characteristics of strains $58 \mathrm{~B}^{\mathrm{T}}$, Gough, and LIL

\begin{tabular}{llll}
\hline \multicolumn{1}{c}{ Test } & \multicolumn{3}{c}{ Strain } \\
\cline { 2 - 4 } & $58 \mathrm{~B}^{\mathrm{T}}$ & Gough & $\mathrm{LIL}$ \\
\hline Aerobic growth (film) & $+(-)^{a}$ & $+(-)$ & $+(-)$ \\
Anaerobic growth (film) & $+(-)$ & $+(-)$ & $+(-)$ \\
Growth on methylene blue agar & + & + & + \\
Clearing on egg yolk agar & - & - & - \\
Film on egg yolk agar & - & - & - \\
Growth without serum & - & - & - \\
Esculin hydrolysis & - & - & - \\
Arginine hydrolysis & - & - & - \\
Urease production & - & - & - \\
Glucose fermentation & + & + & + \\
Maltose fermentation & + & + & + \\
Mannose fermentation & + & + & + \\
Sucrose fermentation & + & + & + \\
Methylene blue reduction & + & + & + \\
Resazurin reduction & + & + & + \\
Tetrazolium reduction & + & + & + \\
Tellurite reduction & + & + & + \\
Casein digestion & - & - & - \\
Phosphatase production & - & - & - \\
\hline
\end{tabular}

$a+(-)$, Growth positive, film negative; + , positive; - , negative. 


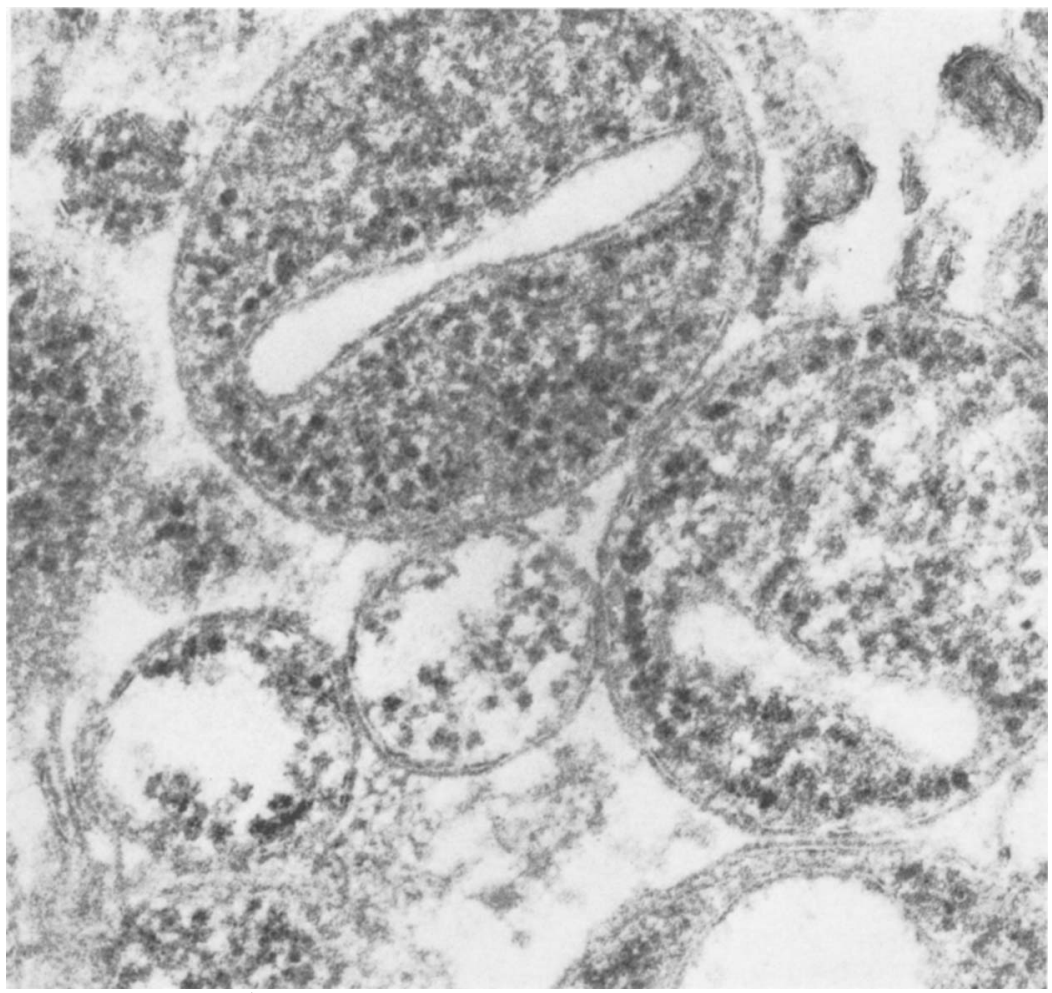

FIG. 2. Electron microphotograph of Mycoplasma strain $58 \mathrm{~B}^{\mathrm{T}}$ stained with uranyl acetate and lead citrate. $\times 38,000$.

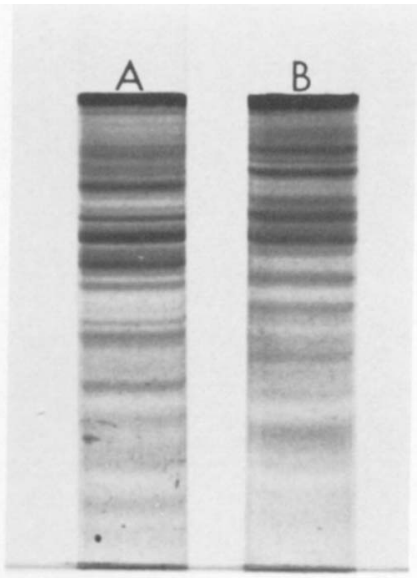

FIG. 3. Electrophoretic protein patterns comparing strain $58 \mathrm{~B}^{\mathrm{T}}$ (lane A) with $M$. pulmonis (lane B).
Strains $58 \mathrm{~B}^{\mathrm{T}}$, Gough, and LIL belong to the same species, as they have similar characteristics and were found to be closely related or identical in the serological tests. As there were no cross-reactions with any of the species listed in Table 1 , strain $58 \mathrm{~B}^{\mathrm{T}}$ is a new species.

I suggest that this new species be named Mycoplasma collis (col'lis. L. gen. n. collis of a hill [intended to allude to the name, in Latinized form, of the author who described this species]). The type strain of this species is strain $58 \mathrm{~B}(=$ NCTC 10197).

$M$. collis must be considered an uncommon inhabitant of rodents. It has been isolated from only three rat colonies and one mouse colony (a more recent recovery was made from the conjunctivas of rats in a colony distinct from those mentioned above), and the organism is easily grown on a conventional medium. However,

TABLE 3. Serological reactions

\begin{tabular}{|c|c|c|c|c|c|c|c|c|c|}
\hline \multirow[t]{2}{*}{ Antigen } & \multicolumn{3}{|c|}{$\begin{array}{l}\text { Growth inhibition (mm) with } \\
\text { antiserum: }\end{array}$} & \multicolumn{3}{|c|}{$\begin{array}{l}\text { Reciprocal of metabolism inhibition } \\
\text { titer with antiserum: }\end{array}$} & \multicolumn{3}{|c|}{$\begin{array}{l}\text { Reciprocal of immunoperoxidase } \\
\text { titer with antiserum: }\end{array}$} \\
\hline & $58 \mathrm{~B}^{\mathrm{T}}$ & Gough & LIL & $58 \mathrm{~B}^{\mathrm{T}}$ & Gough & $\mathrm{LIL}$ & $58 \mathrm{~B}^{\mathrm{T}}$ & Gough & LIL \\
\hline $58 \mathrm{~B}^{\mathrm{T}}$ & $6-7$ & 6 & 6 & 130,000 & 16,000 & 16,000 & 16,000 & 8,000 & 16,000 \\
\hline Gough & 6 & 5 & 5 & 65,000 & 16,000 & 33,000 & 16,000 & 16,000 & 8,000 \\
\hline LIL & 7 & 6 & 6 & 65,000 & 8.000 & 16,000 & 8,000 & 16,000 & 16,000 \\
\hline
\end{tabular}


isolation of $M$. collis might be more frequent if conjunctivas were commonly examined in rats.

Difficulties in infecting rodents with organisms subcultured on an artificial medium have impeded information on the pathogenicity of $M$. collis.

\section{ACKNOWLEDGMENTS}

I thank C. Tram, Pasteur Institute, Paris, France, for taking the electron micrographs and R. Brooks, Medical Research Council Laboratories, Carshalton. England, for the other photographs.

\section{LITERATURE CITED}

1. Aluotto, B. B., R. G. Wittler, C. O. Williams, and J. E. Faber. 1970. Standardized bacteriologic techniques for the characterization of Mycoplasma species. Int. J. Syst. Bacteriol. 20:35-58.

2. Barber, T. L., and J. Fabricant. 1971. Identification of Mycoplasmatales: characterization procedures. Appl. Microbiol. 21:600-605.

3. Clyde, W. A., Jr. 1964. Mycoplasma species indentification based upon growth inhibition by specific antisera. J. Immunol. 92:958-965.

4. Edward, D. G. ff. 1971. Determination of sterol requirement for Mycoplasmatales. J. Gen. Microbiol. 69:205210 .

5. Edward, D. G. ff., and W. A. Fitzgerald. 1951. Cholesterol in the growth of organisms of the pleuropneumonia group. J. Gen. Microbiol. 5:576-586.

6. Fabricant, J., and E. A. Freundt. 1967. Importance of extension and standardization of laboratory tests for the identification and classification of mycoplasma. Ann. N.Y. Acad. Sci. 143:50-58

7. Fallon, R. J., and P. Whittlestone. 1969. Isolation, cultivation and maintenance of mycoplasmas, p. 211-267. In J. R. Norris and D. W. Robbins (ed.), Methods in microbiology, vol. 3B. Academic Press, Inc., New York.

8. Freundt, E. A., B. E. Andrews, H. Ernø, M. Kunze, and F. T. Black. 1973. The sensitivity of mycoplasmatales to sodium-polyanethol sulfonate and digitonin. Zentralbl. Bakteriol. Parasitenkd. Infektionskr. Hyg. Abt. 1 Orig. Reihe A 225:104-112.

9. Hill, A. C. 1971. Mycoplasma cariae, a new species, J. Gen. Microbiol, 65:109-113.

10. Hill, A. C. 1974. Experimental and natural infection of the conjunctiva of rats. Lab. Anim. 8:305-310.

11. Hill, A. C. 1974. Mycoplasmas of small animal hosts, p. 311-316. In J. M. Bové and J. F. Duplan (ed.). Les Colloques de l'Institut National de la Santé et de la Recherche Médicale. INSERM, Paris.

12. Hill, A. C. 1977. The metabolic inhibition test for mycoplasmas based on phosphatase production. J. Hyg. 79:391-393.

13. Kirby, K. S. 1959 . The preparation of deoxyribonucleic acids by the p-aminosalicylate-phenol method. Biochim. Biophys. Acta. 36:117-124.

14. Klieneberger-Nobel, E. 1962. Morphology of pleuropneu- monia-like organisms, p. 23-56. In E. Klieneberger-Nobel (ed.). Pleuropneumonia-like organisms (PPLO): $\mathrm{Mvco-}$ plasmataceae. Academic Press. Inc.. London.

15. Leach, R. H. 1976. The inhibitory effect of arginine on growth of some mycoplasmas. J. Appl. Bacteriol. 41:259 264.

16. Manchee, R. J., and D. Taylor-Robinson. 1968. Haemad sorption and haemagglutination by mycoplasmas. J. Gen Microbiol. 50:465-478.

17. Marmur, J., and P. Doty. 1962. Determination of the base composition of deoxyribonucleic acid from its thermal denaturation temperature. J. Mol. Biol. 5:109-118.

18. McGarrity, G. J., D. L. Rose, V. Kwiatkowski, A. S. Dion, D. M. Philips, and J. G. Tully. 1983. Mycoplasma muris, a new species from laboratory mice. Int. J. Syst. Bacteriol. 33:350-355.

19. Morton, H. E., and R. J. Roberts. 1967. Production of anti-mycoplasma (PPLO) antibodies in rabbits. Proc. Soc. Exp. Biol. Med. 125:538-543.

20. Polak-Vogelzang, A. A., R. Hagenaars, and S. Nagel. 1978 Evaluation of an indirect immunoperoxidase test for identification of Acholeplasma and Mycoplasma. J. Gen. Microbiol. 106:241-249.

21. Purcell, R. H., D. Taylor-Robinson, D. C. Wong, and R. M. Chanock. 1966. A color test for the measurement of antibody to the non-acid-forming human mycoplasma species. Am. J. Epidemiol. 84:51-66.

22. Purcell, R. H., D. Taylor-Robinson, D. Wong, and R. M. Chanock. 1966. Color test for the measurement of antibody to T-strain mycoplasmas. J. Bacteriol. 92:6-12.

23. Razin, S., and S. Rottem. 1967. Identification of mycoplasma and other microorganisms by polyacrylamide-gel electrophoresis of cell proteins. J. Bacteriol. 94:1807-1810.

24. Razin, S., and J. G. Tully. 1970. Cholesterol requirement of mycoplasmas. J. Bacteriol. 102:306-310.

25. Shepard, M. C., and D. R. Howard. 1970. Identification of " $T$ " mycoplasmas in primary agar cultures by means of a direct test for urease. Ann. N.Y. Acad. Sci. 174:809-819.

26. Taylor-Robinson, D., R. H. Purcell, D. C. Wong, and R. M. Chanock. 1966. A colour test for the measurement of antibody to certain mycoplasma species based upon the inhibition of acid production. J. Hyg. 64:91-104

27. Taylor-Robinson, D., M. H. Williams, and D. A. Haig. 1968. The isolation and comparative biological and physical characteristics of T-mycoplasmas of cattle. J. Gen. Microbiol. 54:33-46.

28. Timms, L. 1967. Isolation and identification of avian mycoplasmas. J. Med. Lab. Technol. 24:79-89.

29. Tully, J. G. 1965. Biochemical morphological and serological characterization of mycoplasma of murine origin. $J$. Infect. Dis. 115:171-185.

30. Tully, J. G., and S. Razin. 1969. Characteristics of a new sterol-non-requiring mycoplasma. J. Bacteriol. 98:970978.

31. Williams, C. O., and R. G. Wittler. 1971. Hydrolysis of esculin and phosphatase production by members of the order Mycoplasmatales which do not require sterol. Int. J. Syst. Bacteriol. 21:73-77.

32. Young, C., and A. Hill. 1974. Conjunctivitis in a colony of rats. Lab. Anim. 8:301-304. 